\title{
¿La fe es significativa para el hombre? Olegario González de Cardedal en el Areópago moderno
}

\author{
PILAR SÁNCHEZ ÁlVAREZ* \\ Instituto Teológico de Murcia (España) \\ pisaal@gmail.com
}

\begin{abstract}
Resumen
Olegario González de Cardedal es precursor y pionero de la Nueva Apologética en España, y, aparte de analizar la credibilidad de la revelación por el signo fundamental Jesucristo, en necesario comprobar si la fe es razonable para el hombre del siglo XXI y sí los argumentos que la explican no son contrarios a la lógica. Entre los distintos pasos para indagarlo se parte de que la fe es significativa para el hombre, objetivo fundamental de este artículo. Las fuentes de estudio empleadas han sido cuarenta artículos del teólogo publicados en distintos medios de comunicación, principalmente en los periódicos ABC y El País. En este estudio, siempre desde la visión del autor, se aclarará algunas características antropológicas señaladas por el autor, basadas en las ciencias humanas; la relación del hombre con lo sagrado; los rasgos más característicos de su Antropología Teológica; y por último se dará respuesta a la pregunta: ¿La fe es significativa para el hombre actual? Se termina con algunas consideraciones sobre el tema.
\end{abstract}

Palabras clave: antropología teológica, fe, Olegario González de Cardedal, Nueva Apologética, sentido de la fe.

\section{Is Faith significant for the man today? \\ Olegario González de Cardedal in the moderm Areopago}

\begin{abstract}
Olegario González de Cardedal is recognized as a Theologian pioneer of the New Apologetic in Spain, and, besides analyzing the credibility of the revelation by the fundamental sign Jesus Christ, it is needed to verify whether the Faith remains reasonable for the man on the XXI century, and whether the arguments that explain it are not in opposition to the logic. Among the different steps on such a quest, an starting point is that the Faith provides meaning to the man, which is the main purpose of this article. The sources for this study were forty articles of the theologian in different means, especially on the Spanish newspapers: $A B C$ and El Pais. Along this study, some anthropologic characteristics pointed out by the Theologian are clarified, like those based on the human sciences, the relationship between man and the sacred, the most fundamental aspects of its Theological anthropology, and an answer will be provided to the question: Is Faith significant for the man today?
\end{abstract}

Key words: Theological anthropology Faith, Olegario González de Cardedal, New Apologetic, sense offairh.

* Doctora en Filosofía y Ciencias de la Educación. Doctora en Artes y Humanidades. Doctora en Teología Fundamental. Catedrática de Educación Secundaria. Consejería de Educación de Murcia. Entre los libros publicados: Del primate al hombre y del hombre a Dios (2011); Salud emocional y convivencia (2010); y Prevención de la violencia en la mujer (2008).

Este trabajo forma parte de una investigación para una tesis doctoral titulada "Olegario González de Cardedal en el Areópago. Clarificar la fe y dar razones de su esperanza”, de la Universidad Pontificia Antoniana. 


\section{INTRODUCCIÓN}

Olegario González de Cardedal, uno de los grandes teólogos españoles actuales, no solo valorado por las autoridades eclesiásticas (miembro de la Comisión Teológica Internacional, y de numerosas asociaciones europeas o premio Ratzinger) sino por las autoridades civiles (Académico Numerario de la Real Academia de Ciencias Morales y Políticas, Premio Ortega y Gasset-Espasa Calpe de Ensayo). Identifica e interpreta de manera certera los signos de los tiempos, entendidos no solo en sentido bíblico como presencia escatológica del Reino, sino como valoración de los acontecimientos del mundo actual para poder influir en él con el Evangelio. Tiene una clara conciencia de su misión de creyente, sacerdote y teólogo, ejercida desde una reflexión que tiene en cuenta la tradición hispana y europea, a la vez que dialoga permanentemente con la cultura contemporánea, en su dimensión filosófica, social y política.

El objetivo de este artículo es, mediante un método analítico y hermenéutico, indagar si la fe en Dios es significativa para el hombre en el pensamiento del autor.

Pero antes de comenzar el análisis propuesto es imprescindible partir de las propias palabras del autor, quien afirma que, aunque no se puede demostrar empíricamente, la fe existe evidenciada por la experiencia religiosa sentida por los hombres y la larga trayectoria de la filosofía y la teología.

[...] no es racional ni científica en el sentido de la física o la matemática, pero no por ello deja de ser razonable, como lo son otras realidades de la vida humana no aprehensibles con el método de las ciencias puras. Existen la belleza y la verdad, la sabiduría y la esperanza, el amor y la fidelidad, la confianza en el prójimo y en el otro. El hombre confina con el Absoluto; capaz de dar de sí y de recibir de Aquel. A quien se absolutiza a sí mismo no le queda otro horizonte inmediato que su finitud y otro horizonte último que la muerte (González de Cardedal, 2007a: 328).

La fe es la respuesta del hombre a la autocomunicación de Dios. El teólogo parte de la siguiente pregunta: ¿Se opone la fe a la inteligencia? Cuando Don Olegario (2000) escribe a la muerte de Zubiri un artículo, expone las ideas de este, totalmente asumidas por él:

Porque quería hablar a fondo del problema teologal del hombre, se empeñó en esclarecer los problemas antropológicos. Para ello tuvo que hablar de la inteligencia, de la razón, y del logos. Una vez acabada esta trilogía, retornaba a su originaria inquietud: hablar de Dios, mostrar que el problema teologal del hombre es un problema de raíz personal y de consumación espiritual y 
no primariamente de conceptos, de actitudes o de acciones (González de Cardedal, 2000: 210).

Así mismo este pensamiento está presente en numerosos filósofos como Ernst Tugendhat (2006), Beorlegui (2017), o teólogos insignes como Ruiz de la Peña (1988) o Ladaria (1993). El teólogo que nos ocupa afirma:

Toda teología está constituida por dos dimensiones: la búsqueda y la pregunta por la realidad, la existencia personal y su futuro, y la segunda, por la novedad de una historia ante la que solo espera y le da esperanza. Por este motivo la teología es antropología porque debe conocer la estructura y el dinamismo del hombre que ha sido llamado e identificado por Dios. Son dos lenguajes paralelos, porque ambas tienen como objetivo el conocimiento de Dios. El teólogo no puede olvidar al filosofo y el filósofo al teólogo (González de Cardedal, 2002a: 5).

No se puede olvidar la gran aportación del Concilio Vaticano II, porque en Gaudium et spes por primera vez en la historia de la Iglesia, se expresa la idea cristiana del hombre.

Hablar del hombre en Don Olegario es hablar de Dios; y al comentar la importancia de las enseñanzas de Santa Teresa de Jesús asegura que esta radica en su conocimiento del hombre, no como el resultado de la especulación, sino en la experiencia de "Dios, en la fidelidad y el amor, en la atención interior a sí misma y a quien la alumbra: por eso termina fascinándonos, porque lo que en ella encontramos es todo lo humano llevado a su mejor expresión por la presencia sorprendente de Dios" (González de Cardenal, 2015: 225). Luego conocer a Dios es conocer al hombre y viceversa.

¿Cuáles son los cuatro grandes temas de la teología según Olegario González de Cardedal? Para él, los grandes temas son: Dios, hombre, la relación entre ellos dentro de la historia y el futuro de estas relaciones. Estos temas son siempre nuevos, pues cada generación las analiza bajo unas perspectivas olvidando otras. Toda pregunta sobre Dios, pasa siempre por la pregunta sobre el hombre, porque en el seno del hombre está la conciencia de Dios (González de Cardedal, 2002a).

Para responder a la pregunta inicial se analizará el concepto actual de hombre, su relación con lo sagrado, algunas características de la antropología teológica del autor y se terminará el estudio con algunas propuestas ofrecidas por González de Cardedal. 
1. AlgunAS CARACTERÍSTICAS ANTROPOLÓGICAS SEÑALADAS POR EL AUTOR, BASADAS EN LAS CIENCIAS HUMANAS

\subsection{Concepto del hombre}

Una preocupación constante de todos los pensadores cristianos, tanto filósofos como teólogos desde la antigüedad hasta el momento actual es el tema del hombre (González de Cardedal, 2005). "En ninguna época se ha sabido tanto y tan diverso con respecto al hombre como en la nuestra...Y sin embargo, en ningún tiempo se ha sabido menos acerca de lo que el hombre es" (Heidegger, 1993: 177).

El hombre ha sido objeto de estudio de diversas ciencias, dando lugar a las distintas antropologías, aunque ahora no se va a partir del hombre como ser solitario, sino en relación con el otro, porque precisamente las ciencias han demostrado que la alteridad es factor constitutivo de su identidad (González de Cardedal, 2000). El que el hombre piense, hable, sienta, muestre afecto, demuestra que es un ser social, y por tanto, necesita a los demás (Alonso, 2018).

Para estar sano, es necesario tener buenas relaciones consigo mismo y con los demás, es decir, las relaciones intrapersonales y las interpersonales deben ser satisfactorias, siendo en las interpersonales necesario la figura del otro, porque ese otro es el que obliga a la persona a salir del aislamiento (González de Cardedal, 2000). Al estudiar su identidad, descubre en su interior un anhelo a la verdadera belleza, al bien supremo, a la infinitud, a la eternidad, que no es otra cosa que el Tercero-Trascendente (Gesche, 2010). El hombre debe a la Verdad, a esa suprema Belleza, al Bien Supremo, a ese tercero Transcendente una gratuita e incesante servidumbre (González de Cardedal, 2000).

Una vez aclarada la íntima vinculación entre el hombre y Dios en su pensamiento, el teólogo analiza al hombre desde el punto de vista de los aspectos físicos y las manifestaciones sociales y culturales de las comunidades humanas, es decir, aceptando al hombre como es y sus exigencias de humanidad, para caminar hacia una antropología teológica, es decir, a presentar al hombre desde el punto de vista de la revelación, estableciendo la visión cristiana del hombre.

\subsection{El hombre como un todo. Necesidades del hombre}

El ser humano no puede dividirse en parte material y parte espiritual como se ha concebido en posicionamientos tradiciones. En el hombre todas las dimensiones están interrelacionadas; es una unidad psicosomática, 
es la unión sustancial de cuerpo y alma, de materia y espíritu. Las transformaciones que se producen en la sociedad, producen cambios en las personas, pero como estas son unidades integrales, estas transformaciones se producen en todos los ámbitos, y cambian las maneras de pensar, de sentir y de actuar, es decir, los conocimientos, las actitudes, los sentimientos, los valores, expresados en sus comportamientos (González de Cardedal, 2000). La Biblia presenta una visión del ser humano en la que la dimensión espiritual aparece junto a la dimensión física, social e histórica del hombre (Gn 2,7), y esta imagen está en consonancia con la visión psicosomática de la ciencia actual.

El hombre, como todo ser vivo tiene necesidades biológicas y a la vez, por ser racional posee unas necesidades espirituales, en interacción constante, y tanto unas como otras, son esenciales, y deben ser satisfechas (González de Cardedal, 2007a). Afirma el teólogo:

El hombre es un amasijo de necesidades: físicas, biológicas, sociales, morales, espirituales y religiosas. Diferentes entre sí, religadas y articuladas, todas ellas deben ser reconocidas y respondidas tanto en el orden personal como en el orden social. El hombre necesita pan y agua, aire y luz, belleza y amor, justicia y esperanza. Cada una de ellas cumple su función directa, pero a la vez colabora en la realización de las demás, porque está afectada de la insatisfacción del órgano cuando se lo separa del organismo. Todas ellas deben encontrar en la sociedad apoyo, defensa y cultivo (González de Cardedal, 2011b: 3).

Don Olegario entiende necesidades humanas como:

... menesteres, impulsos o fuerzas motivadoras, suscitadas por una carencia, tensión, desequilibrio o apetencia que mueven al sujeto a realizar unas acciones que llenen ese vacío, descarguen esa tensión, recuperen el equilibrio anterior, y logren el objetivo anhelado. Tenemos por consiguiente, un doble elemento: por un lado la carencia, posibilidad o impulso existentes en la persona y por otro la percepción, respuesta y acción del propio sujeto, o bien de la sociedad, del grupo o de las otras personas, en orden a corresponder a aquella disposición carencial o potencial (González de Cardedal, 1996c: 523).

El hombre nace desprotegido por la naturaleza, y no solo en el aspecto físico, "sino en todos los ámbitos y necesita a los demás para vivir y crecer" (González de Cardedal, 2007a: 191). El teólogo hace una descripción poética del hombre utilizando metáforas oportunas, unas sobre la indefensión en el nacimiento y en los primeros años, otras sobre su origen en Dios y la libertad que le concede. Como ejemplo de ellas se puede leer: 
El hombre viene al mundo con sus alforjas llenas de mendrugos de pan, unas colodras de agua y unas pocas palabras primordiales. Con ellas nombra todas las cosas, las estrellas arriba en el cielo, los ríos avanzando hasta la mar y los árboles cabalgando hacia la altura. Ellas dicen su nombre exacto, el que revela su misma esencia asomándose al semblante y revelándose enteras. Sabe el hombre del origen divino de esas palabras, que el sembrador de estrellas hizo sonar en sueños, como primera música y llegar a sus labios como ola humilde y humedecedora. Entregadas al hombre, este puede malgastarlas y profanarlas, afondarlas con sus experiencias y ensancharlas con sus esperanzas. Puede ir oscureciéndolas por la violencia que les infiere, pero también puede con el uso irlas volviendo más diamantinas y cenitales (González de Cardedal, 2008b: 3).

\subsection{Necesidad de los otros y del Otro}

Otra de las necesidades fundamentales del hombre es la de filiación (Maslow, 1943), el relacionarse con los demás. El hombre surge a la existencia, a la libertad y a la dignidad en un doble movimiento, desde dentro hacia fuera, y desde fuera hacia dentro (González de Cardedal, 2007a). Lo esencial de la vida humana, el amor, la esperanza, siempre es dado por otro (Zubiri, 1993). Hay un legado que el hombre al nacer recibe de las generaciones anteriores, bien con palabras, bien con gestos o signos, o bien con textos escritos:

La casa del hombre se sostiene en cuatro columnas: realismo ascético de la acción, penetración perforadora del pensamiento, recogimiento actualizador de la memoria y anticipación proyectiva de la esperanza. Pero cada uno de nosotros solo puede construir una pared de esa morada vital, encender unos fuegos, plantar unas semillas. La mayor parte de lo que necesitamos lo recibimos de los demás por la palabra viva; y, cuando esta ya no es posible, por la lectura (González de Cardedal, 2000: 45).

Los antropólogos y los psicólogos han demostrado que el ser humano, a diferencia del animal, nace totalmente indefenso y remitido al acogimiento y atención que le otorgan los demás. Desde pequeño, a través de la madre, nace a la palabra, a la inteligencia, y siempre hay un "otro", que influye a lo largo de la vida. Es entonces cuando surgen las necesidades de la solidaridad comunitaria y del destino histórico. Toda la vida posterior al nacimiento tendrá como uno de sus fundamentos de estabilidad, las caricias o no caricias de los primeros años, y la atención o no atención, recibida en edades tempranas: 
El hombre como animal es el más indefenso, necesita a los demás, no solo en lo físico sino en todos los órdenes de la vida. Aprende en la escuela, en la familia, en la calle. La educación abarca información de necesidades objetivas y conformación del sujeto personal. Desde todas las ciencias del saber y de sentido se ilumina la realidad humana como posibilidad dada a los que inician existencia. A la vida personal uno se abre por las ideas recibidas y por las actitudes percibidas, por lo que uno oye explicado y por lo que ve previvido en quienes nos transmiten esos saberes (González de Cardedal, 2007a: 191).

El hombre nace en una familia, pertenece a una nación con un estado donde rigen unas leyes, unas normas... Gracias al lenguaje hereda conocimientos, técnicas y valores, imposibles de adquirir por sí solo (Gadamer, 2002). Esos beneficios recibidos de la sociedad, revierten otra vez en ella, porque todo hombre comparte y comunica sus propias creaciones, porque no está hecho para la soledad, sino para la comunicación con los demás (Zubiri, 1994). La sociedad humana es una institución natural, fundamentada en la propia naturaleza humana.

Libremente y por mutuo acuerdo, los hombres fundan o establecen sociedades concretas y particulares, con elementos esenciales, geográficos, culturales e históricos específicos (Florero, 2012). Por consiguiente, el fundamento natural de la sociedad humana, permite comprender lo que la sociedad tiene de libre y de necesario, es decir, aquellos elementos que dependen de la libertad humana y los que se fundamentan en la propia naturaleza del hombre:

El hombre, por tanto, solo llega a ser hombre con la ayuda de los otros hombres: generación, educación; transmisión del lenguaje; de los símbolos y de la tradición; propuesta de modelos de vida; invitación a tareas históricas; confianza otorgada, ayuda en necesidades cotidianas o situaciones límite; amor que engendra, alimenta y sostiene la libertad" (González de Cardedal 2007a: 217).

La idea de relación está presente en González de Cardedal, “todo lo que es personal, del fondo de la vida humana, tiene que explicitarse en la comunidad" (González de Cardedal, 2007a: 182). Este apoyo en el otro se explicita como "confianza fundamental". Esta confianza es lo que da origen, sostiene, acompaña y espera. Esta confianza se manifiesta cuando el otro da amor o tiene la autoridad y el reconocimiento por parte del que confía. Eso es ser hombre, confiar y creer o no creer, en quien te "da origen, te sostiene, te acompaña y te espera" (González de Cardedal, 2013a: 3). La confianza implica reciprocidad. Se deposita la confianza en 
el otro al comprobar que no defrauda y, al mismo tiempo, porque se experimenta que también uno es objeto de confianza.

Es decir, se recibe de la familia, de la sociedad, del entorno próximo y lejano toda una serie de influencias condicionantes, aceptadas o no según las circunstancias, donde la confianza es fundamental, pero a la vez, el hombre posee la libertad, por la cual elige entre opciones diferentes y eso es precisamente lo que le permite no estar determinado. Estas dos ideas antropológicas son fundamentales: se puede confiar en los otros, pero somos libres de confiar o no confiar.

Cuando el hombre reflexiona sobre sí mismo descubre su indigencia, la apertura, la capacidad de interrogarse a la vez que necesita ser preguntado; y descubre su propia responsabilidad. Indigencia, apertura, capacidad de interrogarse y responsabilidad es lo que reconoce el hombre sobre sí mismo.

$\mathrm{Y}$ es entonces, cuando se reconoce desvalido, lleno de carencias, con necesidad de abrirse a los demás, cuando se pregunta a sí mismo sobre la realidad que le rodea, cuando busca en su interior la respuesta a las eternas preguntas, y descubre como influye en el mundo, sobre los otros y sobre sí mismo, entonces, sobre estas cuestiones de su propia naturaleza, brota la pregunta sobre Dios y a la vez, descubre la libertad.

El hombre siempre es un Misterio incluso para sí mismo. Lo primero que debe hacer el hombre es reconocerse y aceptarse, asumir las situaciones, e incluso superarlas, sin resignación pasiva. Estas dos acciones hacen al hombre libre: junto a la admiración por las cosas, ha de ir del asombro ante el hecho de que existe, de que la nada no le domina, sino que está puesto en la luz de la realidad.

Cuando volvemos la mirada a la historia de los hombres nos sorprendemos de la larga marcha, del lento proceso que nos ha llevado desde la materia a la vida, desde la vida a la conciencia, desde la conciencia a la libertad y desde la libertad a su realización en las formas ejemplares, que se expresan por el heroísmo, la santidad, la creación artística, el servicio incondicional al prójimo, la espera incondicional en Dios, el martirio. ¡Qué dura y constante tarea de forja, de tallado y gubia, ha necesitado ese busto personal del hombre para ir pasando del que los romanos llamaban el homo romanus al homo bumanus y de este al bomo christianus, es decir, de lo particular nacional, a lo común a todos los hombres y de esto a una realización en cercanía a lo divino tal como el mismo Dios nos lo ha hecho posible por los hombres inspirados, desde los poetas a los profetas y desde los cantores de la esperanza a los genios de la caridad (González de Cardedal, 2007b: 3).

¿Puede el hombre perder la dignidad alcanzada? Al final de este artículo, escribe: 
Pico de la Mirándola, al comienzo de su discurso «Sobre la dignidad humana», pone en boca de Dios estas palabras dirigidas al hombre: «No te he dado un lugar determinado, ni rostro propio, ni don particular, a fin de que tu lugar, rostro y dones los conquistes y poseas por ti mismo... Tú podrás degenerar en formas inferiores, como las de las bestias, o, regenerado, alcanzar las formas superiores que son «divinas» (González de Cardedal, 2007b: 3).

\subsection{Sentido de las preguntas del hombre}

Entre las cualidades inherentes en el hombre está la comunicación con el otro, pudiendo hacerse preguntas él mismo y contestando a las preguntas de los demás. El hombre, desde que tiene conciencia de ser hombre, se preguntó, y continúa haciéndolo, sobre su ser y su destino, "porque no solo quiere alimentos, poder y sueño, porque, dormido o despierto, no puede esquivar las preguntas por el sentido y la verdad, la salvación y la culpa, la gracia y la esperanza, por sí mismo y por Dios" (González de Cardedal, 2007a: 72).

Se ha hecho preguntas metafísicas relativas a su existencia, al mundo, a la totalidad; preguntas antropológicas sobre su ser, su sentido, su salvación; preguntas escatológicas o última finalidad; preguntas estéticas sobre la belleza en todas sus opciones; preguntas éticas sobre el bien y el mal.

González de Cardedal analiza las preguntas constantes del hombre y recuerda las de Kant: ¿qué puedo saber?, ¿qué debo hacer?, ¿qué me está permitido esperar?, ¿qué es el hombre? A estas responden la metafísica, la moral, la religión y la antropología. "El hombre es el animal que se interroga, que irremediable, perenne e indefectiblemente pregunta por las cosas, por si mismo, por su quehacer dentro del mundo, y sobre todo, por su altísima e inconfundible identidad personal" (González de Cardedal, 2008a:120).

\subsection{El hombre como un ser de fronteras}

El hombre es verdaderamente hombre, por lo que es y por lo que puede ser, lo que le da un carácter sumamente complejo:

El hombre está dotado de un "exceso" de realidad a la vez que de una "carga de posibilidad", que le llevan mas allá de lo que necesita para pervivir, alimentándose y no muriéndose. Aquí arranca el problema real de la ética como determinación del hombre que para ser necesita lo aparentemente innecesario, viéndose ya religado a lo que todavía no es real sino solo posible y por lo que, estando lejos y todavía siendo invisible a sus ojos, puede arriesgar la vida por su conquista (González de Cardedal, 1996b: 510). 
$\mathrm{Al}$ situarse en el mundo descubre que tiene deseos de perfección, de plenitud, ansía la infinitud, aunque se da cuenta de sus límites. Se puede definir como el ser de horizontes y de fronteras porque se encuentra en la cima de dos mundos, donde convergen las dos laderas, la de la materia y el espíritu, la finitud y la infinitud. Es frontera, entre la materia y Dios (González de Cardedal, 2010: 3).

\section{CONCEPTO DE RELIGIÓN Y LAS FUNCIONES QUE REALIZA}

El hombre recibe una religión al nacer y una de las muchas preguntas surgidas entre los creyentes y los no creyentes, es la naturaleza de la religión. González de Cardedal (2011a) la define como una forma de ejercitación de nuestra existencia que afecta a todos sus niveles y se expresa como reconocimiento de una Realidad Sagrada percibida como presencia y promesa, don y salvación. Puede concebirse la religión como la respuesta del hombre ante la experiencia interior de la existencia de algo superior a él, que le provoca sentimientos y le induce a determinadas conductas, creencia aceptada por grupos sociales que buscan valores trascendentes. $Y$ ese algo superior a él lo contempla como sagrado, siendo lo sagrado lo contrario a de lo profano:

A pesar de todo en Occidente vivimos en lo sagrado, en lo religioso, en lo mágico, en lo fantástico. El Señor de los anillos de Tolkien y la saga de Harry Potter, de Rowling, resultan ininteligibles de no tener presente que el ser humano queda insatisfecho con lo que hay. El anthropos se alimenta de presencias pero asimismo se sustenta con lo ausente. Tolkien ofrece la eterna lucha, mil veces contada, entre el bien y el mal mientras Rowling recrea aventuras y personajes extraordinarios, cuentos inmemoriales. Por lo visto lo corriente y usual sabe a poco. Se ha dado otro paso con Scorsese - La Ultima tentación de Cristo-, con Dan Brown -El Códice da Vinci-, con Salman Rushdie - Los versículos satánicos-e inclusive con precipitadas lecturas del gnóstico Evangelio de Judas como han llevado a cabo los massmedia según costumbre suya. Estos últimos tratamientos y sus éxitos dejan en sus puras carnes que lo sagrado llama vigorosamente la atención. Si el hombre no andara vertebrado por la dimensión religiosa, la práctica de desprestigiar al cristianismo o al Islam no disfrutaría de tantos lectores o de tantos espectadores. Aquello que no nos concierne, simplemente nos resbala. Igual nos desentendemos de un Dios Mayúsculo pero andamos como mínimo tras los divinos Ulises que nos salen al paso (Fullat, 2007: 43).

González de Cardedal (2007a) define la religión como una estructura de la conciencia, que no sustituye ni al derecho ni a la moral, porque el 
sujeto de la religión es la persona en libertad y asociada a la comunidad que se orienta hacia la Verdad, Bondad y Belleza, hacia Dios. Él escribe:

La religión no es una fase de la historia humana, determinada por una geografía, cultura o conjunción de potencias y apetencia, sino una estructura de la conciencia que de manera diferenciada se manifiesta en cada época, creando sus propias encarnaduras. De ella han nacido la moral, la literatura, el arte, la política. Son hijas suyas, no su matriz. Ella es siempre mayor, siempre anterior, y sobrevive siempre a sus hijas. Y engendrará nuevas criaturas, si es vivida desde su lógica y exigencias propias. La religión vive delante de la ética, de la cultura, de la metafísica y de la política, pero no vive al servicio de ellas ni con permiso de ella (González de Cardedal, 2000: 451).

2.1. Comprensiones existentes de la religión en el pensamiento actual

El cristianismo aparece en la conciencia humana como una religión y es imprescindible aclarar las tres compresiones actuales de ella (González de Cardedal, 2002b).

1. Compresión funcional que responde: ¿para qué sirve?, ¿cómo contribuye a satisfacer las necesidades del hombre? La palabra clave es la eficacia y el centro es la sociedad.

2. Compresión real o substancial: explica el sentido religioso para quien la vive voluntariamente, quien lo admite como válida en sí misma en relación con la trascendencia sagrada. La palabra clave es el sentido y el centro es el hombre.

3. Compresión religiosa o teológica: está reconociendo los signos de Dios en la historia, acoge la presencia divina y le responde a esa llamada. El centro no es el hombre sino la revelación de Dios que voluntariamente se manifiesta; el centro es lo Sagrado, el Dios personal. La palabra clave es la gracia y el centro es Dios. Esto es lo específico de la religión cristiana.

La teología cristiana tiene que afirmar la universalidad, la racionalidad y la eficacia humanizadora del cristianismo dentro de cualquier cultura y en cualquier generación. Su centro está en el Dios personal que se revela al hombre (González de Cardedal, 2011b).

\subsection{Carácter universal de la religión}

¿Tiene carácter universal la religión? La religión tiene rasgo universal (Severiano, 2002), está en todas las culturas del mundo, tanto espacialmente como temporalmente, aunque hoy, ante el problema de la secularización, se está poniendo esta afirmación en evidencia por algunos soció- 
logos que dudan de su universalidad, pero la inmensa mayoría de los estudios siguen insistiendo en que la religión es universal (González de Cardedal, 1997a), porque el número de personas que creen en el mundo sigue siendo constante, aunque en Europa hay un profundo descenso. Y tampoco es cierto que se asocie la religión con los países pobres o incultos, porque Berma en Future Cast: What Today's Trends Mean for Tomorrow World, basado en numerosas encuestas de opinión en Estados Unidos se ocupa de la creencia y la práctica religiosa y expone los siguientes resultados: la pertenencia religiosa se ha mantenido muy estable, con un $84 \%$ de personas que se consideraban cristianos en 1991 y un $85 \%$ en el 2010; señala también que sólo la mitad de los adultos pertenecen a una iglesia. Un dato desconcertante es el aumento de formas alternativas de iglesia: iglesia hogar o cyberiglesias, junto a los cambios de tradiciones religiosas, siendo la católica la gran perdedora. Estos datos podrían dar una visión falsa si se quieren extrapolar a Europa, ya que en una encuesta publicada en Pew Research Center: HomeSurvey ReportsThe American-Western European Values Gap de 2011, se evidencia unas diferencias significativas entre los países. Los valores estadounidenses difieren de los europeos en muchos aspectos, ya que estos son más individualistas y religiosos que los europeos occidentales. Hoy las categorías teológicas están presentes en el debate filosófico y cultural.

Las necesidades religiosas fundamentales no han cambiado desde los tiempos del Paleolítico (Eliade,1998). El hombre moderno, al igual que sus antepasados, tiene necesidad de fe, de la pertenencia a una comunidad, de la celebración de ritos y de una ética.

Hay un hecho fundamental para entender la religión: el hombre reconoce su indigencia. En un principio las creencias fueron animistas porque asignaron a los fenómenos naturales alma y estos, desconocido para ellos, les impresionaron en lo más íntimo de su ser. Adoraron al mar, a las tempestades, al sol, a los eclipsis, a las montañas, a los terremotos, a los volcanes. Se realizaron ritos con hechizos, encantamientos y actuaciones mágicas, proliferaron los amuletos, el totemismo, todo lo necesario según sus mentalidades, para influir sobre estos fenómenos, estos dioses que intervenían en el devenir del hombre. También ante las experiencias traumáticas, se quiebra el sentido en el grupo familiar, lo que les lleva a atribuir un sentido diferente a su propia existencia (Aguilar \& Suárez, 2001). Las creencias religiosas aparecen en prácticamente todas las civilizaciones conocidas, y en los pueblos más recónditos de África, América u Oceanía, suelen compartir rasgos comunes y experiencias similares, aunque con el matiz distintivo de la cultura en la que se desarrollan.

Las creencias del cristianismo transforman totalmente esta concepción del dios lejano y útil para mostrar al Dios Amor. Al hablar de religión 
afirma que es un hecho humano universal vivido desde el origen hasta el presente (González de Cardedal, 2007a) "El cristianismo no existe fuera del hombre" (González de Cardedal, 2000: 100).

\subsection{La religión forma parte de la cultura}

La religión forma parte de la cultura y en toda cultura hay unas creencias religiosas (Sarró, 2007). No se puede entender la historia sin lo que la religión ha aportado en el orden del pensamiento, formas comunitarias, propuestas morales, y realizaciones culturales, con su vida, culto y personalidades señeras en el orden de la santidad, el profetismo y la mística (González de Cardedal, 2007a). Todos los seres humanos se comunican mediante el lenguaje, es decir, por medio de las palabras o signos, pero también usan el lenguaje simbólico, porque el hombre expresa experiencias, sentimientos difícilmente expresables con palabras o con signos. Se recurre a los símbolos para expresarlas, mediante metáforas, analogías, comparaciones, etc:

No tenemos los humanos acceso directo a la realidad sino mediante la palabra que nombra, recuerda, invoca, promete, exige, ora, canta y crea. No comprendemos la naturaleza del lenguaje si lo vivenciamos como fórmulas matemáticas o signos telegráficos, que aún no hemos logrado simplificar del todo. El lenguaje es una forma de vida, deriva de las posiciones totales con las que las personas se afirman en el mundo y arraiga en actitudes últimas. Las palabras tienen una constitución símbolica, que hace imposible entenderlas hasta el fondo sin verlas nacer y sin oirlas al ser proferidas por un sujeto humano. Por ello, la palabra es el arca sagrada que nos conserva los tesoros de todas las experiencias humanas, de todas las añoranzas y de todas las expectaciones. La palabra es así la mediación de la realidad. Incluso la realidad misma de Dios no la tenemos sino oyendo nombrarle, invocándole, refiriendo su historia, anticipando su promesa (Gonzalez de Cardedal, 2000: 241).

El símbolo aparece en algunos terrenos de la experiencia humana y surge naturalmente en actividades psíquicas, poéticas y religiosas. Su rasgo fundamental es ser una imagen cargada de afectos, por lo que el significado transmitido se sitúa en el nivel pre-conceptual, sensible y afectivo. Y los símbolos se entienden dentro de una cultura, tocan la esencia de la religión. Los seres humanos se comunican y reciben comunicación, mediante signos y símbolos, y si son experiencias colectivas, esta comunicación simbólica se realiza mediante rituales establecidos por las tradiciones de cada cultura: 
Estas expresiones pueden caer en ritualismos o magia si no se entienden, y así ha sucedido en muchas religiones. Estos ritos, prácticas y símbolos sin sentido han ejercido una atracción, han seducido a muchas personas, por la sencilla razón de que mediante un esfuerzo o un ejercicio relativamente simple y siempre controlable, se consigue un efecto que no suele estar a su alcance o rebasa sus capacidades. Esto es lo que explica la seducción, ejercida por la magia y las Nuevos Movimientos Religiosos sobre mucha gente (González de Cardedal, 2010: 3).

2.4. ¿El hombre tiene la necesidad de relacionarse con lo sagrado?

Desde todas las ciencias de las religiones, se ha buscado una interpretación para comprender la necesidad del hombre de relacionarse con lo sagrado en todos los momentos de la historia conocida, del reconocimiento de una realidad exterior a él que influye en su vida.

Siente esa realidad exterior como "el absolutamente otro", siendo ese otro, bien poder, bien realidad absoluta, bien persona, etc., dependiendo de las circunstancias de cada sociedad. Esa fuerza exterior es superior y responde a sus aspiraciones, creando símbolos y rituales para asegurarse la intervención divina, llamada hierofanía.

Para su propia explicación ha recurrido a la magia, sometiendo lo divino al hombre, al panteísmo, al panenteísmo o al monismo, situaciones pasadas asociadas a sociedades incultas, pero presentes hoy en la civilización occidental. Los cristianos consideran la Encarnación realizada en Jesucristo la hierofanía más sublime conocida en la historia. Dios hecho hombre es lo que se conmemora en la Encarnación.

La cantidad de folclore religioso, de tradiciones populares, de prácticas mágicas, de supersticiones, de ritos y celebraciones, etc., dan evidencia de que el hombre en todos los tiempos ha necesitado comunicarse con lo sagrado, se ha asombrado, lo ha temido, ha ideado recursos para ponerse en contacto con Él. La pregunta es qué producen todas esas manifestaciones en el hombre, qué significado tienen para él, y cómo lo interpreta. González de Cardedal (2011d) afirma que sociólogos recientes como N. Luhmann, J. Habermas o U. Beck aluden a la recuperación de la religión en una sociedad plenamente secular, dentro de la cual podría cumplir ciertas funciones como:

1. Complemento de sentido tanto para la vida personal como para la interpretación del todo.

2. Aportación de recursos para superar la angustia-finitud.

3. Capacidad de crear lazos comunitarios.

4. Generación de consuelo y esperanza más allá de la inmediatez. 
5. Ritualización estética de la vida.

6. Motivaciones para el obrar moral.

\subsection{Funciones de la religión}

Una vez analizadas someramente algunas particularidades de la religión, las funciones asignadas por distintos sociólogos a las religiones, es interesante comprender las funciones que González de Cardedal le asigna.

El conoce el impacto de la secularización y de la modernización, su influjo en ella, las variaciones producidas, y la creación de subsistemas dentro de la sociedad, perdiendo influencia el ámbito religioso en los demás subsistemas y, ante esta información negativa incide en su existencia (González de Cardedal, 2007a).

Don Olegario (2000) establece que la religión (alude al cristianismo) abre al hombre a un rostro personal invocado como Dios, y entre sus funciones está dar sentido al ser y al hombre, convertirse en meta de sus aspiraciones, dar valor a sus valores, consistencia a su finitud, una posibilidad eterna a la temporalidad, a toda belleza, a toda alegría, el ser un factor de paz y de esperanza, pero si es degradada o corrompida puede ser factor de violencia y de opresión.

Una idea que asusta al autor es la recuperación funcional de la religión en la sociedad secular, porque transforma la fe en un servicio meramente utilitario a la sociedad y a la cultura, y solo ejerce una función social, o bien la tienen en cuenta por la eficacia moral (González de Cardedal, 2000); pero teme también a aquellos que comprenden la religión como sustancial o real, porque solo remiten a ella por el sentido que proporciona a la existencia y a la historia humana. Porque la religión cristiana es algo más que funcionalidad o anestesia para la angustia del hombre: es el amor revelado definitivamente en la cruz donde Dios, en su Hijo Jesucristo, padece, comparte y supera el destino del hombre, mortal y pecador (González de Cardedal, 2000).

¿Qué ofrecen las religiones al hombre? Las religiones ofrecen salvación, ofrecen esperanza.

Cuando el teólogo presenta los saberes fundamentales en la formación del hombre, especifica que es necesario preparar a las nuevas generaciones como hombres, como ciudadanos, como profesionales y como habitantes del cosmos en cuanto tierra y del mundo en cuanto comunidad humana (González de Cardedal, 1985). La religión “....abre a un orden de realidad sagrada del que recibe sentido, esperanza, salvación” (González de Cardedal, 2007a: 72). Es decir, da esperanza, le saca de su finitud, de la soledad. En definitiva, prometen felicidad. 
Luego la función de la religión para Olegario González de Cardedal (2007a) es dar sentido a la vida, dar esperanza y proponer la salvación. González de Cardedal habla del Dios.

Entonce el cristianismo es una religión más. Pero el cristianismo, respecto a las demás religiones presenta una novedad absoluta: la Encarnación. Por tanto, es una religión y una fe. González de Cardedal (2007a) parte del descubrimiento que produce la adhesión creyente a la revelación del Misterio de Dios en Jesucristo.

\section{AlguNAS CARACTERÍSTICAS DE SU ANTROPOLOGÍA TEOLÓGICA}

\subsection{Influencias en su antropología}

La credibilidad del acto de fe supone una antropología, supone un hombre capaz de Dios, no solo en el inicio de esa fe, sino para fortalecerla y aumentarla (Albornoz, 2016).

En la antropología de Don Olegario ha influido: la griega (el hombre existe en la naturaleza, y se comprende a sí mismo, y al el mundo como espectáculo); la judía y cristiana (delante de Dios, llamado, visitado y enviado por Él); la de Agustín, Descartes, Kant (ante sí mismo, desde su certeza intelectual y la conciencia de su dignidad moral); el pensamiento dialógico, personalismo, movimientos sociales, Jonas, Balthasar o Levinas (delante del otro y con sus hermanos en la historia como responsabilidad) y el concepto de hombre del Concilio Vaticano II.

Anteriormente se ha indicado que el hombre tiene múltiples necesidades, y una de ellas es la de encontrar explicación a su origen, al sentido de la vida, a la muerte:

Hay necesidades físicas como el pan, el vestido y el cobijo; necesidades sociales como el acogimiento y reconocimiento por los demás; necesidades morales como la defensa de nuestra dignidad y nuestros derechos; necesidades espirituales como el conocimiento del mundo real, la cultura en cuanto forja del propio proyecto personal; necesidades religiosas como la ordenación a Dios, realidad sagrada que nos funda y cobija, que puede alumbrarnos un último sentido y ofrecernos definitiva salvación. Estas necesidades no se viven en pura sucesión cronológica, sino que están imbricadas entre sí y cada una repercute sobre las otras (González de Cardedal, 2008c: 3).

Y sigue afirmando Don Olegario, que todas estas necesidades tienen satisfacción en la concepción cristiana del hombre. Es decir, el cristia- 
nismo muestra una correlación hermenéutica entre lo que anhela el hombre y lo que ofrece la revelación, porque hay una imposibilidad de una autosalvación inmanente en la historia.

3.2. Novedad del Cristianismo respecto a las demás religiones

El teólogo lo expresa con las siguientes palabras:

La afirmación esencial del Cristianismo es que Dios ha descendido hasta ese hombre creado para tales ascensiones (se refiere la a la búsqueda de lo bello, lo alto, el absoluto El Bien, la Idea, La Belleza, el ideal moral) ha compartido su destino, ha gustado su pasión de existir y así se le ha revelado como amor. (...) Lo más esencial no es lo que el hombre hace o tiene que hacer, sino lo que Dios ha hecho por el, la precedencia divina, que abre un camino para que el hombre marche hacia un encuentro personal con él (González de Cardedal, 2007a: 369).

El cristianismo, como todas las religiones, responde a las preguntas del hombre y calma sus anhelos, pero el cristianismo presenta una gran novedad respecto a todas: "Al venir a la historia Cristo, trajo toda la novedad trayéndose a sí mismo" (González de Cardedal, 2000: 279). Es la máxima expresión de Amor.

a) Donación de Dios al hombre y aceptación de este, de forma humilde y gratuita, de su propia existencia

Dios se da al hombre. Para el creyente, Dios es la absoluta gratuidad, y se da al hombre, antes que el hombre a Él. Por mantener esa presencia en la historia, el hombre reconoce la experiencia cristiana originaria, al Dios creador, a su Hijo redentor y al Espíritu vivificador, y acepta, al reconocer su indigencia, de forma humilde y gratuita, su existencia dada por Dios:

El hombre cobra su ser desde la implantación de la realidad y recobra su libertad desde el acogimiento agradecido de esa agraciante implantación en Dios mismo. Le están confiados al hombre su ser y su destino; y al saber, y no poder ignorar este acontecimiento, que es fruto de la confianza, surge la posibilidad de la libertad (González de Cardedal, 2000: 210).

b) El hombre es imagen de Dios, imagen de Cristo

Cuando González de Cardedal (1996b) habla del hombre como imagen de Dios, afirma que el hombre es imagen de Cristo, porque el único 
medio de ser imagen de Dios es reproduciendo la imagen de Cristo, porque con él [Cristo] supimos de la raíz metafísica de nuestro ser, del origen del mundo y del destino de la historia, porque en él estamos fundados, a él fuimos conformados y con él destinados (Col 1, 13-20).

c) La antropología teológica debe evolucionar

El hombre está abierto a la historia humana anterior, sin ser juez de ella. Pero a la vez, no puede quedarse anclado en concepciones antropológicas obsoletas, sino que debe evolucionar con el ritmo de los tiempos: “... se intenta vivir esa misma fe en una relación con la compresión antropológica de la modernidad, mostrando como la experiencia cristiana originaria y la experiencia determinante de la conciencia moderna, no tienen que ser antagónicas, sino que pueden ser cooperadoras de la misma plenitud a la que el hombre tiende" (González de Cardedal, 2000: 186).

d) Dios crea al hombre como ser relacional. Necesita a los otros y al Otro

El hombre es existencia en relación por su ser constitutivamente referido; está ordenado al otro y desde este aserto, surge una ontología, una ética y una teología, porque solo ante la alteridad se reconoce a sí mismo, y con él, aparece el consentimiento y el rechazo, pasando la racionalidad a segundo plano, entrando en juego la voluntad, la libertad, el amor y el desamor.

"No es bueno que el hombre esté solo. Voy a hacerle una ayuda adecuada" (Gn 2, 18). Reflexionando sobre la soledad del hombre escribe González de Cardedal:

La soledad es un reto cuya fecundidad depende de la respuesta que se le dé. En este caso una difícil respuesta porque no dependerá tanto del hombre que está solo, quien por definición no es capaz de ayudarse, cuanto del prójimo y de la sociedad en la que el hombre esté solitario. El hombre está remitido al otro en el origen que le hace ser, al tú que le permite consistir y al que definitivamente le sostendrá en su desistimiento tras la muerte. Por ello sólo una cultura de la projimidad y del amor puede ser una respuesta a una soledad creciente, padecida como una condena y no como introducción a una misión o preparación para un amor (1996a: 175).

El hombre necesita al otro, a los demás. En el mundo actual se cuestiona la existencia de los conventos de clausura, tachándolos de inútiles. En el libro Carta a mi hermana Concha (1973) Don Olegario hace un elogio al silencio de las religiosas de las órdenes contemplativas, al afirmar 
que el silencio elegido por estas religiosas, es una soledad acompañada y dialogante con Dios, y una entrega a los hermanos. Es la misma soledad acompañada de Cristo en la Cruz, una soledad buscada, querida y entregada a los demás. Por tanto, en la clausura hay un modelo de relación del hombre con el "Otro", y a través de Él, con los demás.

e) Solidario con los hermanos en el presente. Está encargado del hermano

Con el prójimo, por su relacionabilidad, la conciencia sabe de él y sabe también de sí mismo (González de Cardedal, 2013c). Dios, como prójimo absoluto, viene por la palabra y por la faz del prójimo, y con El, adquiere sentido su vida.

El cristiano trata a los demás como hermanos. La idea de González de Cardedal (1996a) es, sí Dios fue prójimo de nosotros hasta morir, cada hombre se convierte en un prójimo más allá de su dignidad material, valor moral o actitud respecto al mundo. Por tanto, el hombre está encargado del hermano. "Este poder hacer se convierte en tener que hacer, funda la máxima grandeza y dignidad del hombre" (González de Cardedal, 2013c: $3)$.

El hombre es libre en la medida en que es "entregado", es decir, en la medida en que vive "tradición" y se "entrega" a los demás. Así, redimido de sí mismo, tiene capacidad creadora y posibilidades liberadoras para el prójimo (González de Cardedal, 1993b). Y también recibió de Cristo el encargo de confirmar en la fe a sus hermanos (Lc 22, 31), pero no dominarlos, porque el mensaje evangélico es claro: "Todo cuanto queráis que os hagan los hombres, hacédselo también vosotros a ellos".

f) El hombre es creado creador. Se relaciona con todo lo creado

El hombre solo se humaniza en solidaridad con la tierra, con el trabajo creador, y en solidaridad con los demás hombres. Amor a todo lo creado. ¿Por qué esta actitud de amor a todo? Porque Dios ha creado al hombre creador, pero no dueño del mundo, ni del prójimo.

El hombre no es dueño de lo creado. Dios se lo ha dejado para perfeccionarlo y al final de los tiempos llevarlo de nuevo a su creador. A la luz de la revelación, el hombre no es un espectador del mundo, sino colaborador de Dios en la obra de la creación. Dios ha entregado al hombre, en el último día de la creación, la tarea de desarrollar las fuerzas ocultas escondidas en la naturaleza. Esto implica respeto a la naturaleza (González de Cardedal, 2000). 
¿En que se basa ese precepto cristiano de amor a los demás? En el dogma cristiano sobre la esencia de Dios: Dios es uno y trino. La afirmación de la vida trinitaria de Dios implica, el reconocimiento absoluto del otro como otro, la constitución de nuestro yo por la relación con él y, la consiguiente renuncia a forjar nuestra identidad desde la autorrelación excluyente.

Esto lleva consigo claras consecuencias antropológicas:

- $\quad$ el yo no se constituye solo desde dentro a fuera, ni desde su soledad, sino desde fuera a dentro, por la acción del otro.

- el otro es así mediador indispensable de mi realización y mediador de la voluntad irreducible del Otro.

- se percibe también que alguien en la particularidad de una existencia irreductible pueda ser el mediador de la revelación de Dios y de la salvación del hombre, tal como lo reconocemos al confesar a Jesús mediador absoluto del Absoluto para el hombre.

- la alteridad así pensada es el principio de identidad por la diferencia y de la novedad en la gratuidad. La sorpresa de la existencia tiene fundamento metafísico.

- su concepto de la vida es plenamente cristiano, la vida es un don de Dios, y si se comprende así, solo se puede acoger con agradecimiento y valorando infinitamente este don, y por tanto, se debe conservar y cuidar. Los niños no nacidos tienen derechos que no se les pueden cercenar, y considera el drama de Europa el rechazo de la vida en un sentido y su apropiación en otros.

- su visión cristiana de la existencia humana con un principio y un origen en Dios y cuya meta está en Él, hace que el paso de una situación a otra deba ser reflexionada como un encuentro tan anhelado por el hombre, porque el tiempo no se agota cuando se termina el tiempo finito, sino que ese futuro le da sentido y esperanza, lo ama y lo purifica para llevarlo a la consumación divina.

Esta característica relacional, muestra al hombre nuevo como imagen de Dios, porque la vocación del hombre al Absoluto que le funda, y la versión del Absoluto hacia el hombre, ha tenido su concreción máxima en la historia, en el hombre Jesús de Nazaret, imagen visible del Dios invisible.

Y Jesucristo es Dios y es hombre, es Padre y es Hermano (González de Cardedal, 2012b: 3). 
g) El hombre tiene necesidad de valores espirituales. En la jerarquía de valores, que el hombre debe alcanzar, no se pone como valor supremo la posesión, el tener, sino el Ser

El hombre es un animal, pero se diferencia de los animales y ha ido evolucionando en su propia compresión, desde que tiene conciencia histórica, oscilando en su acepción, en algunos casos positiva (por ejemplo, Rousseau) o negativa (por ejemplo, Hobbes) adoptando también posturas intermedias de un extremo a otro:

Cuando volvemos la mirada a la historia de los hombres nos sorprendemos de la larga marcha, del lento proceso que nos ha llevado desde la materia a la vida, desde la vida a la conciencia, desde la conciencia a la libertad y desde la libertad a su realización en las formas ejemplares, que se expresan por el heroísmo, la santidad, la creación artística, el servicio incondicional al prójimo, la espera incondicional en Dios, el martirio. ¡Qué dura y constante tarea de forja, de tallado y gubia, ha necesitado ese busto personal del hombre para ir pasando del que los romanos llamaban el homo romanus al bomo bumanus y de este al homo christianus, es decir, de lo particular nacional, a lo común a todos los hombres y de esto a una realización en cercanía a lo divino tal como el mismo Dios nos lo ha hecho posible por los hombres inspirados, desde los poetas a los profetas y desde los cantores de la esperanza a los genios de la caridad (González de Cardedal, 2007b: 3).

Desde su formación universitaria en 1962, siempre junto a la reflexión sobre el misterio del Dios, ha elaborado un pensamiento sobre la vida del hombre. De la idea estática y abstracta, fue desarrollando una antropología sobre el hombre de carne y hueso, en el dinamismo de su vida, en las situaciones históricas determinadas, es decir, en el hombre concreto (Cordovilla, 2006).

El verdadero progreso humano está en los valores superiores: el amor, la amistad, la oración, la contemplación. El ser humano está en continua evolución; fue creado por Dios a su imagen y semejanza, pero esta imagen, deformada por el pecado, es llamada libremente a renovar la imagen del Creador por la obra redentora de Cristo, mediante un proceso de identificación como Hijo de Dios, que al final de los tiempos será plenamente imagen de Dios, destinado situaciones históricas determinadas, es decir, el hombre transformado a semejanza de Cristo, en imagen perfecta del $\mathrm{Pa}$ dre. Y así afirma que el verdadero progreso humano está en los valores superiores: el amor, la amistad, la oración, la contemplación: en ser imagen de Dios. 
h) El hombre libre buscador de la verdad. Verdad de Dios y libertad del hombre correlativas

Cuando desarrolla estas palabras, admite la dificultad de dar una definición cerrada sobre ellas. ¿Qué es la verdad? Recurre a buscar sinónimos y antónimos para llegar a una compresión de ella (González de Cardedal, 2011c). Si buscamos sinónimos diríamos: veracidad, autenticidad, fidelidad, objetividad. Si buscamos antónimos tendríamos: mentira, engaño, falsedad, mera apariencia, dolo o doblez. No hay verdad, cuando no respetamos las cosas, al prójimo, a nosotros mismos, porque la vida y las cosas están al hombre entregadas para conocerlas, servirse de ellas y transformándolas cuando es posible, pero respetándolas siempre en sus exigencias objetivas, sin violentarlas, ni destruirlas.

Siguiendo el pensamiento del teólogo verdad, anhelada por el hombre, es objetividad, precedencia, anterioridad.

¿Pero donde se encuentra esa verdad? Cuando se hace esta pregunta, está respondiendo al ansía de apertura del hombre, respondiendo a esa apertura con el Dios revelador. La verdad, por tanto, es el descubrimiento de la realidad divina en un acontecimiento histórico que tiene nombre personal: Jesucristo, el Señor de la Historia.

Afirma que el cristiano debe pensarla y buscarla. No se puede permanecer abúlico porque la verdad sale al encuentro del hombre, sin imposiciones, como oferta dada con amor:

La verdad se nos ofrece y nosotros la encontramos, porque ella nos sale al encuentro. No se impone, invita; y quien la ha encontrado la agradece como una gracia y la ofrece con amor a los demás como un don. Todo don, en última instancia, remite a quien nos ha dado el existir, el movimiento y la vida (cf. Hch 17,28). La verdad está en nuestro inicio, pero a la vez es camino y meta. Y hay Alguien que es el Camino, la Verdad y la Vida (cf. Jn 14,6) (González de Cardedal, 2004: 19).

Por tanto, esa verdad nos remite al origen, al fundamento y al sentido de lo real que nos precede. La verdad para el cristiano está en Cristo, en Dios. Es imposible construir una antropología completa sin tener en cuenta la dimensión cristológica del hombre.

¿Qué es la libertad en la comprensión cristiana? Si la verdad se remite al origen, fundamento y sentido de lo real que nos precede, la libertad es el camino, el espacio abierto para llegar a una verdad final, resultante del ejercicio de la propia iniciativa y del encuentro, conocimiento, diálogo y servicio a la verdad. 
Para definir la libertad acude también a sinónimos y antónimos tales como autonomía, independencia, emancipación, liberación, pero también por sus antónimos como esclavitud, dependencia, sujeción. La libertad es, en progresión creciente, indeterminación, emancipación de, capacidad para, responsabilidad con. Se es libre de los límites negativos, desde el amor recibido y para el prójimo encontrado.

¿Que hay detrás del binomio Verdad/Libertad? Lo que hay detrás es Dios/hombre. ¿Y quién es el sujeto de derechos?, ¿la verdad o la persona?, ¿los principios generales o el hombre individual?, ¿derechos de la verdad abstracta, o de la persona concreta?

Aparecen dos posturas claramente diferenciadas: una verdad ahistórica o una verdad que tengan en cuenta las coordenadas de espacio y tiempo, considerando el tiempo como "la posibilidad que le es dada al hombre, de decidir en libertad sobre sí mismo hacia lo Definitivo" "No somos solo el tiempo que nos queda, sino también la eternidad que nos espera” (González de Cardedal, 2012c: 3).

Para responder a estas preguntas hay que poner el principio siguiente: "Es un error considerar verdad y libertad como realidades extrínsecas una de la otra" (González de Cardedal, 2012c: 3). Dios creó al hombre libre para dialogar con Él. Por tanto, solo se manifestará la verdad en la medida que el hombre sea libre, lo descubra, y tenga fe en Él.

Verdad/libertad. En la antropología teológica de González de Cardedal, la verdad de Dios y la libertad del hombre son correlativas: solo existe la una con la otra. Se es hombre desde la verdad para la libertad y desde la libertad para la verdad. $Y$ ambas remiten al Amor.

La libertad del hombre viene de la verdad y encamina hacia la verdad en descubrimiento, obediencia y creatividad. La libertad implica asumir riesgos y exige aceptar responsabilidades. Pero ambas remiten al amor porque la verdad sin amor es dictadura, y la libertad sin amor, lleva a la soledad, al vacío. "No hay libertad sin projimidad. Aquella solo existe cuando se parte de alguien, se comparte con alguien y se convive con alguien; cuando alguien habita nuestra soledad y nuestra compañía enciende la estancia, oscura y solo desde el amor se mantiene la fortaleza y la esperanza" (González de Cardedal, 2007a: 3). Dios, para el cristiano, es definido como el prójimo absoluto del hombre que le ha hecho surgir en amor desinteresado y gratuito para que exista en libertad.

¿Cuál es la verdadera Humanidad? Verdad, Libertad y Amor resumen la verdadera bumanidad.

El cristianismo es la religión de la razón y del amor y como unión de razón y amor, es la religión de la libertad (Hegel). No hay cristianismo ni verdadera religión sin razón, sin amor y sin libertad. Solo un Dios razón, amor y 
libertad es digno del hombre y solo un hombre viviendo conforma a ellas es digno de Dios (González de Cardedal, 2007a: 368).

i) El hombre descubre a Dios-Amor y, por tanto, misericordioso con el hombre

Afirmado que el hombre es creado por Dios y este, rompiendo su alianza establecida se enfrenta a Él, ¿por qué perdona Dios al hombre? ¿qué mueve a Dios a dar el perdón?

La respuesta es "porque las entrañas de Dios se desbordan de Amor" Dios es ante todo Dios de ternura y, por serlo, es Dios de piedad, compasión y misericordia (González de Cardedal, 2011a: 3). Él mira en primer lugar a nuestro ser de hijos salidos de sus entrañas y fruto de su amor; en segundo lugar, se compadece de nuestra pobreza y tiene misericordia de nuestra debilidad; en tercer lugar, nos ofrece perdón de nuestros pecados. Este es el orden en que hay que pensar de Dios: ternura, misericordia y compasión, perdón. Esas son sus entrañas, que nos ha revelado visitándonos en su Retoño, que surge, retoña o nace de ellas (González de Cardedal, 1997b).

Si Dios es ternura, misericordia, compasión, perdón. ¿el pecado carece de importancia?

Pecar no es una banalidad: es un atentado contra la propia existencia y la de los demás, hace salir al hombre del orden pensado por Dios para él, lo que le convierte en un extraño para sí mismo, y siente a Dios, su Padre, como al gran extraño: "El perdón no trivializa el pecado sino que revela toda su potencia, destructividad y peso ontológico" (González de Cardedal, 2007a: 369).

En el Comentario sobre la encíclica de Benedicto XVI Dios es amor, Deus caritas est, González de Cardedal (2007a) afirma que la encíclica se titula Dios es amor, es decir, Dios es una libertad amorosa que por la plenitud de esa felicidad vivida engendra otros seres justamente para que participen de esa libertad, para que sean sus colaboradores en el mundo, y para que se gocen existiendo, y va a subrayar que la libertad sólo existe si un amor nos precede, nos acompaña y nos espera. Dios ama al hombre y busca su salvación: Se afirma que Dios es amor y da un mandamiento nuevo que es el amor: amor a Dios y amor a los hermanos.

j) El hombre es un ser en proceso de formación, un ser en camino buscador de la perfección que aún no posee 
El ser humano está en continua evolución; fue creado por Dios a su imagen y semejanza, pero esta imagen, deformada por el pecado, es llamada libremente a renovar la imagen del Creador por la obra redentora de Cristo y la acción del Espíritu, y al final de los tiempos, será plenamente transformada a semejanza de Cristo, en imagen perfecta del Padre.

El hombre creado a imagen de Dios, destinado al final de los tiempos a unirse a Él, creado libre, se enfrenta a su propio creador, que por amor, se hace hombre, y por su muerte, lo redime. Esta idea está bien expresada por Teilhard de Chardin (Sequeiros, 2017).

Esta idea la expone al presentar la figura de Teilhard de Chardin, científico que ve en Cristo la presencia particular de un Absoluto y de un Universal. Es Dios, que está en el origen pero que los atrae y planifica hacia delante, porque es el punto final de toda la creación. Cristo como Principio y Cristo como Fin. Así sitúa a Cristo a la luz de los textos bíblicos que le ven en el origen, en la constitución y en el final de toda realidad (Col 1,16); a los textos litúrgicos que en el corazón de la eucaristía se dirigen a Dios por Cristo, ya que en él "nos creas, santificas, vivíficas, bendices y nos das todas las cosas".

Estos textos que sitúan a Cristo en relación con la creación están ahí desde siempre y Teilhard remite expresamente a ellos. "A Cristo se le ama como a una Persona y se impone como un Mundo" (González de Cardedal, 2007a: 114).

La idea esencial de este científico es que Cristo es el Omega de la evolución, el punto final, tanto en sentido vertical como horizontal. Con esta afirmación converge el científico, el pensador y el místico que era Teilhard, hoy silenciado, aunque sus ideas se empiezan a recuperar en el momento actual.

Sigue afirmando el autor que después de Rahner, el teólogo ya no puede pensar a Dios y a Cristo en desconexión del hombre; después de Teilhard ya no se le puede pensar al margen del dinamismo del cosmos y de la historia, por la sencilla razón de que confiesa a Cristo, como presencia viva de Dios en el corazón de la materia, como el Alpha y Omega. Cristo principio y fin de todo lo creado. Principio y fin del hombre (González de Cardedal, 2004).

k) El cristiano espera la salvación. Se pregunta: ¿cuándo?, ¿cómo? ¿dónde?

La salvación, la respuesta ante la muerte, al deseo de inmortalidad, siempre ha sido una preocupación para el hombre, y en el momento actual, en esta sociedad secularizada y laica, este tema es importante para aclarar a los cristianos dudas y angustias. 
Y para dar respuesta a esta preocupación es necesario acudir a San Pablo. Pero ¿qué busca el hombre?, ¿qué es la salvación, ¿qué es lo que espera el hombre?

González de Cardedal para expresar las realidades determinantes de la vida humana muestra que son: verdad, sentido, esperanza, presente sano, futuro reconciliador, y todo esto los cristianos lo expresan con una palabra: salvación. Y esta salvación está en relación con Dios, porque la plenitud del ser y del propio hombre están en continuación con el acto creador.

La salvación para el cristiano es participar en la gloria de Cristo, inaugurando los nuevos cielos y la tierra nueva. Dios es la esperanza del hombre y su salvación (González de Cardedal, 2002a).

\section{1) Diálogo en el camino}

En ese caminar hacia la perfección se da el diálogo de Dios y el hombre; Dios sale al encuentro del hombre, se revela a él y este responde a la llamada con la fe, que le llevará después de este mundo a la unión con El.

Pero entre ese origen del hombre y el final de su existencia está el tiempo vivido, la respuesta del hombre a Dios (González de Cardedal, 2012a). Don Olegario afirma:

Y en este caminar de todo lo creado hacia Dios, el hombre creado libre, puede aceptar o rechazar esa llamada amorosa de todo un Dios. Un Dios comprendido como trascendencia sagrada que se revela en la inmanencia mediante cuatro categorías: creación, revelación, encarnación y resurrección; que provoca escándalo y fascinación porque lo piensa desde su finitud y siente miedo, temor y envidia ante El, pero siente a la vez, fascinación porque lo define desde otra dimensión, trascendencia (desde el amor y el perdón), justicia (da su propia vida), santidad (solidaridad con el destino de los mortales); un Dios que no es Deus extra nos o contra nos, sino el Enmanuel, Dios con nosotros, Dios-Jesucristo; donde su justicia no es la que nos exige a nosotros, sino la justicia que Él nos ofrece al compartir la vida y el destino de Jesús que por la encarnación se ha unido en cierto modo con cada hombre, ofreciéndole la posibilidad que el Padre le responda como a Jesús, con la resurrección. La meta del hombre es ser como Dios, y el único camino para conseguirlo es la amistad y comunicación con Él (González de Cardedal, 2013b: 3).

Acude a San Juan de la Cruz, guía del teólogo desde los años de sus estudios en el seminario de Ávila para sintetizar su pensamiento como lo que pretende Dios es hacernos dioses por participación, siendo El por 
naturaleza (Dichos de luzy amor) y el alma se hace deiforme y Dios por participación (Cántico Espiritual) (González de Cardedal, 2007a).

\section{4. ¿LA FE CRISTIANA LE DA SENTIDO A LA VIDA DEL HOMBRE? ¿ES SIGNI- FICATIVA?}

La antropología científica muestra al hombre como una unidad psicosomática, con múltiples necesidades, tanto materiales como espirituales, y de naturaleza relacional, relación basada en la confianza, libre, que se reconoce indigente, y descubre su dignidad, y a la vez, se hace preguntas sobre su existencia, su ser y su destino.

Este hombre, que recibe una religión al nacer en una cultura determinada, descubre en su interior una realidad sagrada superior a él, que le ofrece una salvación, le da esperanza.

Don Olegario al presentar su antropología teológica, va dando respuestas a todas y cada una de las cuestiones planteadas por la antropología, desde el cristianismo. Y las explica desde Cristo, en Cristo y para Cristo.

\subsection{Paradojas de la existencia humana}

Según el teólogo, entre las muchas paradojas de la existencia humana, existen algunas evidentes como son:

- Anhelar más de lo que puede conseguir, porque sus deseos son más grandes que sus verdaderas potencialidades. Anhela el Bien que no puede conseguir por sí mismo. ¿Qué sentido tiene vivir?

Tiene un anhelo de libertad y de autonomía, que analizando el orden biológico y biográfico solo lo consigue por el "otro", cuando lo acepta o la ama; amor que no puede imponer sino aceptar y agradecer. ¿En qué dirección orientar las decisiones de nuestra libertad para lograr en la vida un resultado bueno y feliz?

Prepara, proyecta, anticipa el futuro, pero el futuro le es desconocido. ¿Hay un futuro para el hombre, para nosotros y para las generaciones futuras? ¿Qué nos espera más allá del umbral de la muerte?

El hombre no se conoce a sí mismo hasta que otro le lleva a alturas que el mismo no ha sospechado. Al entrar el hombre en sí mismo se reconoce finito, aunque espera que esto no sea así, porque en ese interior anhela la infinitud. Una paradoja importante y una cuestión presente en el hombre desde el principio de los tiempos, como lo demuestran los múltiples restos arqueológicos encontrados.

Existen cuatro miradas que el hombre puede hacer: 
- Hacia fuera, al mundo

- Hacia arriba, a la trascendencia

- Hacia dentro, a la interioridad

- Hacia delante, al futuro.

Y al analizar estas miradas, descubre al Dios cristiano que le muestra quien es, hacia donde va, y le oferta una salvación distinta a las demás religiones.

Estas miradas no existen aisladas, se implican entre ellas, porque la verdad del hombre habita en estos cuatro ámbitos, produciéndose una circularidad entre ellas: mundo, Dios, a sí mismo y futuro. Cuando el hombre las integra aparece la soledad en compañía y compañía en la soledad, condición para la libertad y fuente de esperanza.

En el momento actual es cierto que se da una desorientación en el hombre, que no cree más que en lo que puede tocar, en lo verificable, sin embargo, estas paradojas están presentes en el hombre, y aunque los avances de la ciencia han sido enormes, el hombre de hoy no es más libre ni más feliz que tiempos anteriores.

La modernidad, intentando salvar el concepto de Dios, lo ha desnaturalizado, convirtiéndolo en primera instancia en fundamento de la ética, o fundamento del cosmos, o fundamento del ser. Se ha buscado el cristianismo como explicación de las necesidades del hombre, con una visión totalmente utilitarista.

\section{2. ¿Qué busca el creyente en Cristo?}

"Al cristianismo no se va porque se necesita nada para ser en este mundo, para dominar la tierra, o para conquistar la felicidad. Quienes buscan directa o exclusivamente estas cosas harían mejor dirigirse a la técnica, a la medicina, a la psiquiatría o a la magia" (González de Cardedal, 2000: 231).

El cristianismo, el buscar a Cristo, no lo puede hacer por funcionalidad, por su utilidad de aquí y ahora. Porque el Dios de la religión, antes que nada, es Misterio de amor personal, no herramienta explicativa para nuestras preguntas éticas, cosmológicas o metafísicas. Solo después de ser identificado en su esencia como amor personal, tal como la entiende Jesús de Nazaret, puede explicar nuestros interrogantes (González de Cardedal, 1993a).

Entre las compresiones anteriormente comentadas, está la compresión religiosa o teológica: la que reconoce los signos de Dios en la historia, acoge la presencia divina y le responde a esa llamada. El centro no es el hombre, sino la revelación de Dios que voluntariamente se manifiesta; el 
centro es lo Sagrado, el Dios personal. La palabra clave es la gracia y el centro es Dios. Esto es lo específico de la religión cristiana.

Es a partir de esta compresión, después de analizar estas connotaciones del hombre, cuando se está en condiciones de afirmar que la concepción cristiana de Dios identificado como Amor, responde a las preguntas metafísicas (relativas al hecho mismo de la existencia, de la totalidad, del mundo); a las antropológicas (sobre el sentido, salvación, vida y muerte); a las escatológicas (o de última finalidad y orientación); a las éticas (el porqué del bien y el mal, libertad, justicia, valores...).

Un Dios creador, como origen de todo lo existente, que crea al hombre libre, a su imagen y semejanza, que se hace hombre y muere para hacer al hombre hermano e hijo adoptivo de Dios, liberándolo del pecado por el mimo Amor que lo había creado, que le da dignidad, esperanza y una manera de vivir; le ofrece, por tanto, respuestas a las preguntas del hombre; y este hombre creado libre puede aceptarlo o rechazarlo.

Luego la visión cristiana del hombre, para todo aquel que la acepta, tiene significado porque responde a cada uno de los anhelos, deseos y paradojas de su interior.

No hay contradicción entre la fe cristiana y la razón del hombre, porque lo que cree, siente, experimenta, espera, anhela como hombre, encuentra satisfacción en lo que ofrece Cristo. La fe es razonable porque no contradice a la lógica humana, no se opone a ella.

Una de las principales tareas de la Teología Fundamental es la búsqueda de la credibilidad y uno de los enfoques de la credibilidad es la búsqueda de sentido, y este incide en la compresión y presentación del cristianismo y en las consecuencias que tiene para la vida. El cristianismo tiene significado para el creyente, porque el Dios Amor, Jesucristo, da respuestas a las preguntas, y responde a todos los requerimientos de su naturaleza como hombre.

\section{3. ¿Tiene significado el cristianismo en el hombre de hoy?}

No se puede terminar esta conclusión sin confrontar todo lo anterior con la mentalidad del hombre de hoy, es decir: ¿Las preguntas sobre Dios son válidas hoy?, ¿tienen sentido todas las razones dadas en tiempos anteriores sobre Dios, donde la cultura era totalmente distinta a la actual?, ¿los hombres del siglo XXI siguen haciéndose preguntas sobre su vida?, ¿esas preguntas tienen validez racional hoy? Es decir, ¿el hombre de este siglo ha cambiado sus inquietudes sobre su religiosidad, sobre su existencia, o su destino?

Para responder a estas preguntas se va a especificar que el hombre puede encontrar a Dios en cualquier ambiente; que en la sociedad actual 
todas las ciencias no demostrativas por la razón tienen dificultades; y por último, hoy se puede dar una respuesta positiva a las preguntas propuestas.

a) El hombre puede encontrar a Dios en cualquier ambiente

Para argumentar sobre la validez de las preguntas que se ha hecho en épocas anteriores, el teólogo recurre a la antropología y a su gran maestro Zubiri.

Afirma (González de Cardedal, 2007a,) que Zubiri en su estancia en París sufre una transformación en su pensamiento, que cambiará su orientación teológica debido a la influencia proveniente de la teología griega, introducida por la inmigración rusa en Occidente, y la conocida "teología de los misterios" propuesta de O. Cassel, asumida mayoritariamente por los benedictinos.

Zubiri leyó la obra de Myrrha Lot-Borodines, que en el año 1932-1933 publicó: La doctrina de la deificación en la iglesia griega hasta el siglo XX, comparando el legado teológico cristiano y acercando a la mentalidad, a las experiencias y a las expresiones cristianas latino occidental, las de las Iglesias orientales.

¿Qué le sucedió a Zubiri al contacto con esta inmigración rusa y la lectura de esta obra? El tenía una formación basada en Descartes, Kant, Santo Tomás, estudió la neoescolástica, con predominio de una actitud moralista, jurídica, que le obligaba a ver el cristianismo de forma racionalista, psicológica y moral. González de Cardedal afirma:

El universo simbólico y sacramental, la celebración litúrgica, como actualización presenciadizadora de la salvación, la acción permanente del Espíritu Santo en la Iglesia, como perenne fuerza constituyente, frente a la mera memoria histórica de Cristo fundador, la significación escatológica de monaquismo, la validez perenne de las grandes figuras teológicas de patrística griega, frente a la absolutización de lo occidental y concentración en lo latino: tal era el legado de la teología griega que ahora aparecía ante los ojos (2007a: 225).

Pero a la vez, la teología alemana traída por numerosos exilados en París, le pone en contacto con otros teólogos como Schmaus, Stolz, quien en 1936 publica Teología de la mística que lo resitúa en "el horizonte histórico, objetivo y bíblico del misterio y en la vida comunitaria de la Iglesia". Así se unía en su pensamiento Biblia, Liturgia y Mística.

Con este cambio de orientación escribe: 
Por muy instalada que esté en el espíritu objetivo, la razón individual conserva siempre la capacidad de abrirse paso por su cuenta (sea para comprender y hasta para confirmar la vía en que se la instalada, sea para comprender una nueva vía), porque la razón es constitutivamente razón abierta (González de Cardedal, 2007a: 225).

Zubiri cambia de perspectiva y se abre a una nueva situación, pero sus preguntas son las mismas, sus inquietudes no cambian, necesita comprender y comprenderse y busca las respuestas con una nueva visión de la vida.

¿Qué significa las palabras anteriores sobre Zubiri? Que a pesar de que las circunstancias sociales no sean favorables para buscar a Dios, para buscar su propio autoconocimiento, el hombre siempre dispone de una razón creativa que puede llevarle a preguntar sobre esas cuestiones de los siglos anteriores y encontrar las respuestas en el siglo en el que vive.

Es decir, aplicándolo a la persona del siglo XXI, aunque el hombre viva en una sociedad secularizada, donde se olvida de Dios, el hombre puede reflexionar sobre su vida, su destino, sobre Dios.

Las preguntas siguen presentes y aunque el entorno no sea propicio a Dios, es indudable que el hombre puede encontrar respuestas a ellas, gracias a la razón creativa.

b) ¿Existe en la sociedad actual especiales dificultades para el estudio de Dios?

El teólogo se pregunta: ¿qué pasa en una cultura donde solo es importante la satisfacción inmediata, donde se elimina el esfuerzo, con afán de dominio sobre todo y donde lo que priva es lo mundano?, ¿en esta cultura no encuentran dificultades la filosofía, la educación, la pedagogía, es decir, todo aquello que obligue al hombre a buscar los valores tradiciones?

Por tanto, la búsqueda de Dios en estos momentos, no tiene distintas dificultades que estas ciencias que hoy también están en crisis. A pesar del imperio de las ciencias empíricas, todas las ciencias del espíritu tienen presencia en la sociedad, aunque estén es crisis, como están las religiones tradicionales.

Luego la teología, como ciencia similar a las ciencias del espíritu, tiene dificultades para existir en esta sociedad, pero su presencia es manifiesta. $\mathrm{Y}$ en este caminar de todo lo creado hacia Dios, el hombre creado libre, puede aceptar o rechazar esa llamada amorosa de todo un Dios.

Un Dios comprendido como trascendencia sagrada que se revela en la inmanencia mediante cuatro categorías: creación, revelación, encarnación y resurrección; que provoca escándalo y fascinación porque lo piensa desde su finitud y siente miedo, temor y envidia ante El, pero 
siente a la vez, fascinación porque lo define desde otra dimensión, trascendencia (desde el amor y el perdón), justicia (da su propia vida), santidad (solidaridad con el destino de los mortales); un Dios que no es Deus extra nos o contra nos, sino el Enmanuel, Dios con nosotros, DiosJesucristo; donde su justicia no es la que nos exige a nosotros, sino la justicia que Él nos ofrece al compartir la vida y el destino de Jesús que por la encarnación se ha unido en cierto modo con cada hombre, ofreciéndole la posibilidad que el Padre le responda como a Jesús, con la resurrección. La meta del hombre es ser como Dios, y el único camino para conseguirlo es la amistad y comunicación con Él (González de Cardedal, 2013b).

c) Se puede dar una respuesta a las preguntas del hombre

La cuestión de Dios se planteó en los siglos anteriores desde la razón y el conocimiento, y hoy se afronta desde la experiencia y el lenguaje.

En la encíclica de Juan Pablo II (1998), Fe y Razón, se afirma que el hombre es capaz de verdad, abierto a la realidad y a la verdad de sí mismo, es decir, se pregunta sobre el sentido de su vida.

Por este motivo, este documento asume el giro antropológico de la modernidad occidental, y las preguntas tradicionales del hombre sobre Dios se unen al sentido de la existencia humana.

Por otra parte, la razón es necesaria para todo y no es suficiente para nada. Mirando los cuadros de Goya se ve como la razón instaura la guillotina y produce monstruos, y enseñan que los demonios están encarnados en sujetos concretos, en instituciones, en vidas personales. (González de Cardedal, 2000).

No todo es razón, porque el hombre es un todo en su forma de pensar, de sentir y de actuar; es inteligencia, percepción, sensaciones, emociones, sentimientos, voluntad.

La sociedad actual busca la eficacia antes que el sentido, quiere productos antes que esperanza, produce de todo, menos ilusión. San Juan de la Cruz, oyente del Misterio, ha enseñando el camino hacia nosotros mismos y hacia Dios, y en el momento que olvida su identidad, no recuerda a Dios, se pierde el camino y hay que dejarse guiar.

Dios no pertenece a un pasado felizmente superado, pues el ser humano no cesa de interrogarse sobre el origen y el fundamento del ser. $\mathrm{Si}$ cualquier hombre puede reconocer que Jesús responde a sus preguntas últimas, a sus esperanzas definitivas, encuentra una respuesta válida e insuperable, porque el cristianismo brota desde las entrañas del ser humano, se verifica desde la experiencia humana.

Luego estas preguntas hoy encuentran respuestas como siempre han encontrado. 
No se puede negar que el Dios representado por distintas tradiciones religiosas, resulta incompatible desde una perspectiva racional y adulta de lo real. Los milagros son una afrenta a la moral si se entienden como la actuación arbitraria de un Dios todopoderoso. Si el Dios que responde a las preguntas del hombre, es la idea de un Dios funcional, un Dios "tapagujeros", el hombre no encontrará respuestas, o serán respuestas que no les satisface. Si el Dios del hombre es el Dios del amor y la paz, el que está ante el hombre, para que cada generación lo encuentre o se deje encontrar por Él, pasando de la razón a la fe o de la fe a la vida, ese Dios dará respuestas a sus preguntas e inquietudes (González de Cardedal, 2000).

\section{4. ¿De qué depende las creencias de los hombres?}

El hombre es libre de buscar o no buscar a Dios. González de Cardedal afirma que el hombre en sus creencias no solo depende de una convicción racional sino de una decisión vital. Puede querer o no querer aceptar la existencia de Dios, puede admitir los testimonios de los creyentes o no aceptarlos.

En su interior comprende que es un ser que está pendiente de ser, que se va haciendo en cada momento y en cada momento decide lo que quiere ser. El se sabe libertad, pero esa libertad la consigue ejercitándola. Y puede hacerse esas preguntas o no hacerlas. Ejerce su libertad decidiendo, consistiendo en su alteridad, porque en soledad ni puede ser hombre ni ser creyente. Para ser hombre necesita del lenguaje, de los signos, de la cultura, de lo conquistado hasta ese momento; para ser creyente necesita al prójimo y la comunidad para llegar a Dios.

Hoy el hombre ve en Dios la amenaza más grave para que las libertades modernas sean posibles. Ante lo conseguido por él, decreta en fin de los poderes establecidos, de las jerarquías, de los credos, de los valores.

Es la generación sin padres, sin señores, sin dueños, sin maestros. Hay que eliminarlos para ser definitivamente libres, para ser dueños de sí mismos (González de Cardedal, 2000: 263).

Pero Dios deja libertad para todo y en consecuencia para no creer en Él. Afirma:

La realidad, la vida humana, la historia ofrecen tanto sentido por sí solas que, para quien quiera conformarse con ellas le resulte suficiente. Ahora bien, quien ha escalado otras cumbres declarará insuficiente esa forma de existencia, proclamará la belleza, plenitud y vida que se ven desde la cima a la que él ha ascendido por sí mismo, o ha sido llevado por otros. Dará testimonio, e intentará mostrar con la totalidad de su vida, que esa propuesta suya es más racional por responder a más exigencias y posibilidades del 
hombre y, por consiguiente, personalmente más fecunda (González de Cardedal, 2000: 264).

Afirma que cuando se ahuyenta a un Dios de la ciudad, toman posesión de ella los dioses. Eso es lo que está pasando en el momento actual. Estos dioses, poder, dinero, funcionalidad, consumismo, impiden al hombre preguntarse por su propio origen, su destino, su sentido de vida, pero a pesar de todos estos inconvenientes, el hombre sigue haciéndose esas preguntas y buscando a Dios. Y Dios es la respuesta para el hombre creyente.

\section{PALABRAS FinALES}

A la pregunta inicial, una vez realizadas las anteriores consideraciones, se puede afirmar que Jesucristo es históricamente y culturalmente significativo porque responde a las necesidades del hombre y a todas las preguntas que se ha planteado en el pasado y sigue haciéndose en el presente, porque no se ha dejado de creer en él, porque hay una comunidad de creyentes para quienes él es la revelación absoluta de Absoluto y por eso, "es fuente de verdad, de sentido y salvación" (González de Cardedal, 2000: $333)$.

\section{REFERENCIAS}

Aguilar M. A. \& Suárez, M. E. (2001). Narrativas y experiencias acerca del sentido de la vida y la muerte: etnografía del dolor y tramas familiares. Sociedad. $e$ cultura, Goiania, 14(2), 345-355.

Albornoz, M. (2016). La dinámica del amor en el logos homilético de John Henry Newman. Teoliteraría, 6(12), 79-95.

Alonso, M. S. L. (2018). Análisis del orden en el que el autoconcepto, la autoestima y la autoimagen deberían aparecer en el proceso de maduración personal para alcanzar el bienestar emocional. International Journal of Developmental and Educational Psychology (Revista INFAD de Psicología), 1(2), 257-264.

Beorlegui, C. (2017). Antropología filosófica: dimensiones de la realidad bumana (Vol. 39). Universidad de Deusto.

Cordovilla, A. (2006). Dios y el hombre en Cristo. El itinerario y el pensamiento teológico de Olegario González de Cardedal. En A. Cordovilla, J. M. Sánchez Caro \& S. del Cura Elena (Eds.), Dios y el hombre en Cristo. Homenaje a Olegario González de Cardedal (pp. 18-49). Salamanca: Sígueme.

Eliade, M. (1998). Lo sagrado y lo profano. Barcelona: Paidós.

Florero, L. (2012). Del grupo armado a una comunidad urbana: integración, acción y participación en la ciudadela de Santa Sosa. (Tesis de pregrado). Universidad del Rosario. Bogotá, Colombia. 
Fullat, O. (2007). Antropología de lo religioso y la educación. Revista pucp edu, 16(31), 44- 62.

Gadamer, H.G. (2002). Verdad y método. Salamanca: Sígueme.

Gesche, A. (2010). El hombre. Dios para pensar II. Salamanca: Sígueme.

González de Cardedal, O. (1967). Teología y antropología. El hombre imagen de Dios en el pensamiento de Santo Tomas. Madrid: Moneda y crédito.

González de Cardedal, O. (1973). Carta a mi hermana Concha. Salamanca: Sígueme.

González de Cardedal, O. (1985). La gloria del hombre. Madrid: Biblioteca de Autores Cristianos.

González de Cardedal, O. (1993a). La nueva racionalidad teológica. En L. Rodríguez (Ed.), La fe interpelada. Jornadas de estudio y diálogo entre profesores universitarios (Documentos de Trabajo) (pp. 281-354). Salamanca: Universidad Pontificia Comillas.

González de Cardedal, O. (1993b). Jesús de Nazaret. Aproximación a la Cristología. Madrid: Editorial católica.

González de Cardedal, O. (1996a). Propuestas españolas desde la religión y la teología. Cuenta y razón, (97), 118-124.

González de Cardedal, O. (1996b). Raíz de la esperanza. Salamanca: Sígueme.

González de Cardedal, O. (1996c, 29 de octubre) Navegar es necesario. Vivir no es necesario. Discurso en la RACMP.

González de Cardedal, O. (1997a). Elmisterio del cristianismo. Salamanca: Secretario Trinitario.

González de Cardedal, O. (1997b). La entraña del cristianismo. Salamanca: Secretario Trinitario.

González de Cardedal, O. (2000). La palabra y la Paz 1975-2000.Madrid: PPC.

González de Cardedal, O. (2002a). Filosofía y Teología. Revista de Occidente (258), 5-35.

González de Cardedal, O. (2002b). ¿Dios funcional o Dios real? Verdad y plausibilidad como problema fundamental de cristianismo contemporáneo. Salmanticensis, (49), 5-58.

González de Cardedal, O. (2004). Dios. Salamanca: Sígueme.

González de Cardedal, O. (2005, 19 de marzo). ¿Qué leer? $A B C$.

González de Cardedal, O. (2007a). Al ritmo del diario vivir. Madrid: PPC.

González de Cardedal, O. (2007b, 21 de noviembre). El político y la monja. ABC.

González de Cardedal, O. (2008a). El Quehacer de la Teología. Salamanca: Sígueme.

González de Cardedal, O. (2008b, 3 de abril). Unas pocas palabras verdaderas. $A B C$.

González de Cardedal, O. (2008c, 8 de julio). Figuras morales frente a ídolos. $A B C$.

González de Cardedal, O. (2010, 13 de febrero). Signos visibles del invisible. $A B C$.

González de Cardedal, O. (2011a, 20 de abril). Pasión de Cristo-Pasión de un Papa. $A B C$.

González de Cardedal, O. 2011b, 30 de junio). ¿'Teólogos, para qué? $A B C$. 
González de Cardedal, O. (2011c). Juventud y verdad. Carta abierta a mi amigo Carlos. En J. Zazo Rodríguez (Coord.), La jwventud. Una reflexión necesaria. Madrid: PPC.

González de Cardedal, O. (2011d, 7 de junio). Dios. El quehacer de la sociología. Discurso en la RACMP.

González de Cardedal, O. (2012a, 1 de septiembre). Examen y cargo de conciencia. $A B C$.

González de Cardedal, O. (2012b, 1 de diciembre). De Bach a Ratzinger. $A B C$.

González de Cardedal, O. (2012c, 31 de diciembre) Entre la alegría y la melancolía. $A B C$.

González de Cardedal, O. (2013a, 21 de junio). Confianza o sospecha. $A B C$.

González de Cardedal, O. (2013b). Dios en la ciudad. Salamanca: Sígueme.

González de Cardedal, O. (2013c, 22 de diciembre). De San Ignacio a Wittgenstein $A B C$.

González de Cardedal, O. (2015). Cristianismo y Mística. Madrid: Trotta.

Heidegger, M. (1993). Kant y el problema de la metafísica. México: Fondo de Cultura económica de España.

Juan Pablo II (1998). Fides et ratio. San Pablo: Madrid.

Ladaria, L.F. (1993). Introducción a la Antropología. Estella: Verbo divino.

Maslow, A. (1943). A Theory of Human Motivation. Psychological Review, (50), 370396.

Ruíz de la Peña, J. L. (1988). Imagen de Dios: antropología teológica fundamental (Vol. 49). Bilbao: Editorial Sal Terrae.

Sarró, R. (2007). Cómo los pueblos sin religión aprenden que ya tenían religión: notas desde la costa occidental africana. Quadern de linstitut Catalá d'Antropologia. Religió, cultura i cognició, 23(6), 103-122.

Sequeiros, L. (2017). Teilhard de Chardin defendido por Henri de Lubac. Revista digital CRT. Disponible en https://blogs.comillas.edu/FronterasCTR/2017/03/08/teilhard-de-chardin-henri-de-lubac/

Severiano, J. (2002). Experiencia de lo sagrado y tradiciones religiosas. Estudio de la fenomenología de la religión. Navarra: Editorial Verbo Divino.

Tugendhat, E. (2006). Antropología como filosofía primera. Estudios de Filosofía, (34), 232-244.

Zubiri, X. (1993). El hombre, realidad personal. Revista de occidente, (1), 5-29.

Zubiri, X. (1994). Naturaleza, historia y Dios. Madrid: Alianza Editorial.

Sumario: Introducción; 1. Algunas características antropológicas señaladas por el autor, basadas en las ciencias humanas; 1.1. Concepto del hombre; 1.2. El hombre como un todo. Necesidades del hombre; 1.3. Necesidad de los otros y del Otro; 1.4. Sentido de las preguntas del hombre; 1.5. El hombre como un ser de fronteras; 2 . Concepto de religión y las funciones que realiza; 2.1. Comprensiones existentes de la religión en el pensamiento actual; 2.2. Carácter universal de la religión; 2.3. La religión forma parte de la cultura; 2.4. ¿El hombre tiene la necesidad de relacionarse con lo sagrado?; 2.5. Funciones de la religión; 3. Algunas características de su antropología teológica; 3.1. Influencias en su antropología; 
3.2. Novedad del Cristianismo respecto a las demás religiones; 4. ¿La fe cristiana le da sentido a la vida del hombre? ¿Es significativa?; 4.1. Paradojas de la existencia humana; 4.2. ¿Qué busca el creyente en Cristo?; 4.3. ¿Tiene significado el cristianismo en el hombre de hoy?; 4.4. ¿De qué depende las creencias de los hombres?; 5. Palabras finales; Referencias. 